\title{
ЩОДО ФОРМУВАННЯ МАСИВУ ДАНИХ НА БАЗІ НЕЙРОННОÏ МЕРЕЖІ У СФЕРІ ІНТЕРНЕТУ РЕЧЕЙ
}

\author{
Козак Є.Б. - магістр у галузі комп'ютерних наук, \\ розробник програмного забезпечення, інженер-програмісm GAN Inc. \\ ORCID ID: 0000-0002-8342-2609
}

У статті досліджено принциипи формування масиву даних на базі нейронної мережі у сфері Інтернету речей. Зазначається, щзо Інтернет речей генерує величезну кількість неструктурованих даних, $і$ аналітика великих даних є ключовим аспектом. Концепція Інтернет речей являє особливу иінність для розвитку бізнесу завдяки даним, які можуть бути отримані від підключених елементів. Сформовано дві теореми, які сприяють розкриттю принциипу обміну знаннями, які можна взяти із взаємодії людина-комп'ютер. Наголошено, щчо присвоєння імені суб 'єкту господарювання повинне включати у себе слова мовою людини, а не абревіатури, коди або двійкове відображення, щуо можуть інтерпретувати лише машини, незважаючи на те, мио останні технічно ефективніші з точки зору простору для зберігання даних або пропускної здатності мережі. Розкрито принципи теорії верифікаціонізму та описано иляхи адаптаџї структури масиву даних. Схематично запропоновано структуру машинних знань, яку представлено шюоо формування масиву даних на базі нейронної мережі у сфері Інтернету речей. Описана структура має три бази знань: гіпотезу, онтологію та параметри. Підкреслено, щзо запропонована інтелектуальна база масиву даних може бути застосована до різних галузей Інтернету речей щзодо автономного обміну та накопичення знань, а платформа, своєю чергою, може використовувати онтологї для інтеграиії пристроїв IоТ з інтелектуальними системами. Описано переваги та недоліки моделі. Так, зазначено, щзо перевагою ичєї моделі є те, щзо датчики Інтернету речей у хмарі можуть навчатися у віддалених датчиків у фоновому режимі, незалежно від затримки мережі, шьо підключається до віддаленої програми, а недоліком є те, щчо затримка мережі може стати вузьким місцем, коли потреба у прийнятті рішень у режимі реального часу зростає. Наголошено, изо реалізачія описаного алгоритму формування масиву даних, а також відповідної інтелектуальної середи дозволить зменшити поріг входження розробників у сферу рішення задач за допомогою нейронної мережі.

Ключові слова: масив даних, штучний інтелект, нейронна мережа, Інтернет речей, сенсор, датчик, інтелектуальна система.

Kozak Ye.B. Regarding the formation of a data set based on a neural network in the field of the Internet of Things

The article investigates the principles of data formation on the basis of a neural network in the field of the Internet of Things. It is noted that the Internet of Things generates a huge amount of unstructured data, and big data analytics is a key aspect. The concept of the Internet of Things is of particular value to business development due to the data that can be obtained from the connected elements. There are two theorems that help to reveal the principle of knowledge exchange, which can be taken from the human-computer interaction. It is emphasized that the assignment of a business entity's name should include words in human language and not abbreviations, codes or binaries that can only be interpreted by machines, although the latter are more technically efficient in terms of storage space or bandwidth network. The principles of the theory of verificationism are revealed and the ways of adapting the structure of the data set are described. The structure of machine knowledge is schematically offered, which is presented in relation to the formation of a data set based on a neural network in the field of the Internet of Things. The described structure has three knowledge bases: hypothesis, ontology and parameters. It is emphasized that the proposed intelligent database can be applied to various areas of the Internet of Things for autonomous exchange and accumulation of knowledge, and the platform, in turn, can use ontologies to integrate IoT devices with intelligent systems. The advantages and disadvantages of the model are described, so it is stated that the advantage of this model is that the sensors of the Internet of Things in the cloud can learn from remote sensors in the background, regardless of the network delay connected to the remote program, can become a bottleneck when the need 
for real-time decision-making grows. It is emphasized that the implementation of the described algorithm for forming an array of data, as well as the corresponding intelligent environment, will reduce the threshold for developers to enter the field of problem solving using a neural network.

Key words: data array, artificial intelligence, neural network, Internet of Things, sensor, intelligent system.

Постановка проблеми. Незважаючи на поширеність пристроїв Інтернету речей (IоT), недостатність машин для адаптивного навчання стає перешкодою для поширення інтелектуальних систем ІоТ. Натепер не вистачає досліджень щодо принципу формування масиву даних у сфері Інтернету речей, яким машини можуть автономно ділитися, коли дані надходять 3 різних галузей або тематичних досліджень. Таким чином, питання, як машини можуть автономно обмінюватися знаннями 3 масиву даних, створювати нові знання та адаптивно вчитися на основі цих знань, щоб вони могли стати застосовними у різних сферах чи тематичних дослідженнях, є актуальним.

Аналіз останніх досліджень і публікацій. Питанню розвитку, реалізації та впровадження Інтернету речей у всі сфери життя сучасного людства приділяється чимало уваги як вітчизняними, так і зарубіжними вченими. Зокрема, А. Семеног [1] здійснив аналіз основних технологій, що застосовуються в умовах формування цифрової економіки, визначив їх сутність, види та способи практичного застосування. Дослідив властивості, потенційні переваги та ризики блокчейн-технології, навів приклади компаній, що його використовують. Визначив основні елементи та ієрархію Інтернету речей.

Перспективи розвитку Інтернету речей та промислового Інтернету речей навели I. Сотник та К. Завражний [2]. Авторами доведено, що погіршення інформаційної безпеки діяльності підприємств та організацій є однією з важливих проблем, що супроводжують розбудову промислового Інтернету речей.

Н. Аксак [3] розкрила методи та моделі розподіленої інтелектуальної обробки великих даних у спеціалізованих комп'ютерних системах. У [4] описуються базові проривні технології сучасного етапу розвитку суспільства: штучний інтелект, Інтернет речей, адитивні технології з використанням 3D-принтера, віртуальна і доповнена реальність, нові матеріали, «хмарні» технології та ін. Аналізуються можливі позитивні й негативні ефекти впровадження згаданих проривних технологій.

К. Балаклеєць та А. Квітка [5] увагу приділили актуальності технологічних трендів, які сейсмічно впливають на економіку, цінності, ідентичність і можливості для майбутніх поколінь.

Iз зарубіжних авторів варто відзначити роботи таких науковців, як: Zhang, Weiping \& Kumar, Mohit \& Liu, Jingqing [6], Cui, Dan \& Liu, Fei [7], Xiao, Han \& Li, Yuanjiang [8], Changsheng Xiang, ZiYing Zhou [9], Han Xiao, Yuanjiang Li [10], Ren Fang, Ma Jian-Feng [11], Naveen, Dr \& Raina, Rohini [12], Li Xinwu [13] та інші.

Проте з огляду на описані наукові набутки за темою питання розкриття принципів формування масиву даних на базі нейронної мережі у сфері Інтернету речей залишається відкритим та потребує детального опрацювання.

Постановка завдання. Мета - дослідити принципи формування масиву даних на базі нейронної мережі у сфері Інтернету речей.

Викладення основного матеріалу дослідження. Дослідження, які використовували аналітику великих даних для вирішення проблем IоT, використовуючи методи машинного навчання, можна об'єднати в чотири сфери, такі як: розумне місто, виробництво (тобто сільське господарство та промислове виробництво), управління будівництвом та охорона здоров'я. 
Домен розумних міст зацікавлений у створенні ефективної та комфортної повсякденної діяльності. Деякі приклади включають забезпечення оптимального маршруту руху транспорту, прогнозування схеми заповнення сміттєвих баків для збору, рекомендування товару на основі свого місцезнаходження та прогнозування споживання енергії в розумних лічильниках. У разі прогнозування енергії допоміжні векторні машини були використані для аналізу минулого споживання енергії та даних про навколишнє середовище будівлі, таких як температура і вологість, що призвело до прогнозованого споживання енергії з різницею 1,7 кВт-год між фактичним та прогнозованим споживанням у часовому вікні.

У галузі виробничого землеробства в [14] автори запропонували виявити симптоми кульгавості у молочних корів. Хворі корови впливають на виробництво молока, симптоми хвороби зазвичай проявляються через неактивну поведінку, наприклад, лежачи протягом тривалого часу. Таким чином, датчики ІоТ були розміщені на коровах для збору даних про їхню активність, таких як час лежання та кількість кроків. Методи машинного навчання виявили три типи поведінки, такі як активна, нормальна та спляча у корів. Випадковий відбір дав точність 91 відсоток, виявлений за 1 день до того, як можна спостерігати деякі візуальні ознаки; i k-найближчих сусідів дав точність $81 \%$, виявлену за 3 дні до того, як їхні симптоми були помітні через візуальні ознаки.

У сфері виробництва технічне обслуговування машин має велике значення для мінімізації перебоїв у виробництві через несправності двигунів. Таким чином, дослідження [15] запропонувало механізм, де було здійснено розміщення 3-осьових акселерометрів на заводських двигунах для збору даних про вібрацію, таких як амплітуда та частота двигунів. За допомогою нейронних мереж удалося зі 100\% точністю визначити несправності в нормальних рухових станах із рівнем довіри від 80 до 99 відсотків.

Управління будівлями можна розглядати як домен, що з'єднує розумне місто та виробничий домен, оскільки їх рішення можуть бути застосовані до обох доменів. Дослідження [16] передбачало рівень заповнюваності будівлі, спостерігаючи за температурою, $\mathrm{CO}_{2}$, об'ємом повітря та даними про кондиціонер. Випадковий відбір був використаний для класифікації даних і дав 95\% точність у прогнозуванні рівня заповнюваності кімнат у будівлі.

Домен здоров'я може бути найбільш поширеним додатком, оскільки пристрої IоT приєднані до приватних осіб. Додатки прогнозують рівень цукру для лікування діабету, оцінюють рівень теплового комфорту на робочому місці та виявляють випадки падіння людини вдома. Також глибоке навчання використовують для виявлення таких випадків амбулації, як ненормальний режим ходьби, звички сну та відвідування туалету. Додаток пропонує рішення в режимі реального часу для виявлення аномальних ризиків для здоров'я за допомогою таких пристроїв, що збирають дані про частоту серцебиття, частоту дихання тощо, і дало точність 94\%. Таке рішення можна розглядати як додаток для розумного будинку, оскільки воно також сприяє підвищенню ефективності щоденної діяльності (наприклад, забезпечення кіберопікуна для людей похилого віку).

Те, як людина може взаємодіяти 3 вебсайтами, може показати, як машини повинні взаємодіяти з іншими машинами. Найважливішою властивістю вебсайту $\epsilon$ те, що його презентація може бути зрозумілою людям. Користувачі можуть семантично орієнтуватися на вебсайтах для досягнення цілей, необхідних для виконання завдання. Вебсайти складаються зі слів мовою, яка зрозуміла користувачам. Крім того, макети вебсайтів розташовані у значущій структурі, що відображає їх 
«інформаційний нахил», отже, користувачі можуть природним чином орієнтуватися, щоб знайти інформацію, яку шукають.

$€$ дві характеристики обміну знаннями, які можна взяти із взаємодії людинакомп'ютер:

Теорема 1. Іменування сутності (тобто об'єкта, властивостей, відносин та послуг) повинне використовувати слова, зрозумілі людині.

Теорема 2. Інформація повинна бути упорядкована семантично таким чином, щоб вона дозволяла людині отримувати значення, дотримуючись іiї структури.

Присвоєння імені суб'єкту господарювання повинне використовувати слова людською мовою, а не абревіатури, коди або двійкове відображення, що можуть інтерпретувати лише машини, незважаючи на те, що останні технічно ефективніші з точки зору простору для зберігання даних або пропускної здатності мережі.

В організації інформації семантично використання онтологій є самою моделлю. Це дозволяє людям отримувати інформацію на основі семантичних запитів.

Філософія знання, або гносеологія, забезпечує розподіл того, як людина отримує знання. Основоположним у цій галузі $\epsilon$ «апріорне» та «апостеріорне» знання. Апріорі отримується за допомогою таких визначень, як класифікація: яблука - це фрукти. А апостеріор отримують завдяки досвіду та спостереженням, наприклад, яблука червоні.

Відхилення від наведеного вище визначення також використовуються для опису ідей та людського розуміння. Апріорі та апостеріорний опис знань паралельні первинній та вторинній якості в розумінні людиною. Первинна якість включає властивості об'єкта, незалежні від спостерігача, наприклад яблуко має вагу, розмір і колір. Вторинна якість відноситься до деяких властивостей об'єкта, за словами спостерігача, наприклад яблука червоні.

Первинні знання вбудовані в онтології, такі як визначення «Якщо грунт вологий, то врожай процвітає».

Вторинні знання отримані з датчиків ІоТ, таких як «грунт сухий».

Отримані знання формуються після висновків, припускаючи, що ще служить показником для процвітання врожаю, наприклад сонячне світло та добрива.

Вторинні знання можуть стати первинними знаннями, коли якість, яку вони описують, можна узагальнити. Подібним чином, коли винахідницьке знання (наприклад, гіпотеза) було науково доведено, описувані ним параметри стають вторинними знаннями. Це узгоджується з теорією верифікаціонізму [17], яка служить основою для запропонованої системи машинних знань щодо формування масиву даних.

Структура адаптована з теорії верифікаціонізму, яка забезпечує розбивку наукових методів. Це школа думок, де знання отримуються в результаті експериментально перевірених спостережень. Оскільки суспільство розвивалося шляхом цього наукового шляху, його рамки для отримання знань за допомогою спостережень можна запозичити для проєктування автономних машин для навчання. Структура машинних знань, запропонована щодо формування масиву даних, показана на рисунку 1.

Структура описує, як датчики Інтернету речей можуть автономно обмінюватися знаннями з іншими датчиками. Вона складається 3 трьох баз даних, а саме бази даних Онтологія, Параметри та Гіпотези. Під час надсилання даних з баз даних датчиків Інтернету речей, послуги позначають відповідно до первинного, вторинного або винайденого рівня знань. Датчики Інтернету речей обмінюються знаннями шляхом реклами та пошуку послуг з іншими датчиками Інтернету речей. 
База даних Онтологія містить правила виведення. Вона бере правила або безпосередньо з інших датчиків Інтернету речей як Первинне знання, або з усталеного визначення онтології, або з іії бази даних параметрів.

База даних Параметрів містить пари даних ім'я-значення. Вона приймає значення або з пристроїв Інтернету речей як вторинні знання, або зі своєї бази даних гіпотез. Вторинні знання можуть стати первинними знаннями після перевірки правил у базі даних шляхом певного індуктивного навчання. Для індуктивного навчання можна використовувати сімейство таких методів машинного навчання, як вивчення правил, класифікація та байєсівський висновок.

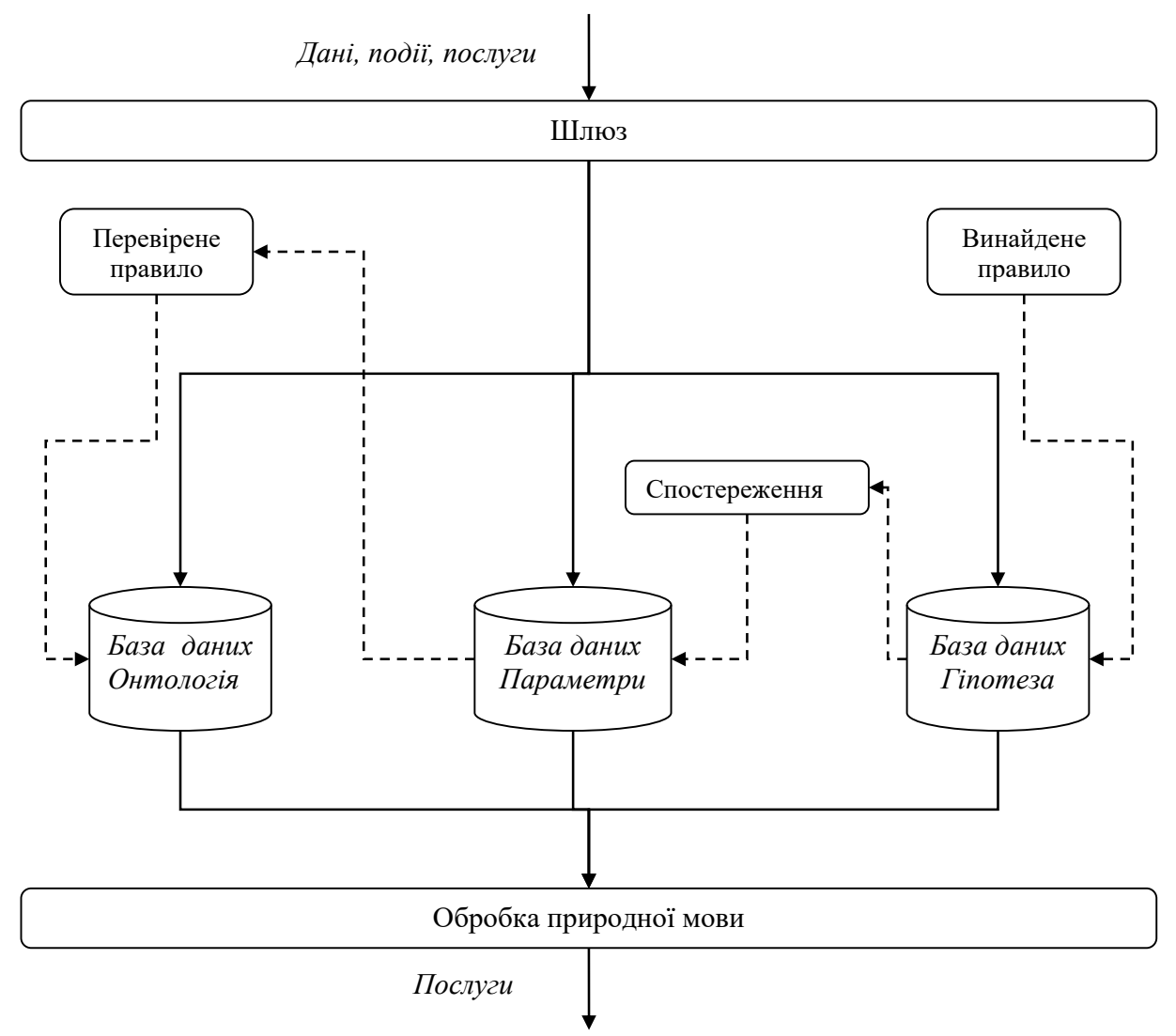

Рис. 1. Структура машинних знань, запропонована щуодо формування масиву даних

База даних Гіпотез містить неперевірені правила виведення. Вона бере правила або безпосередньо з інших датчиків Інтернету речей, як Винайдені знання, або з будь-якого визначення Онтології, або з його бази даних Онтології. Винайдені знання можуть стати вторинними знаннями після деяких спостережень за тим, що значення збіглися до розподілу чи шаблону. Для спостереження за розподілом даних можна використовувати статистику.

База даних Гіпотези також навчається з бази даних Онтологія. Первинні знання 3 бази даних Онтології можуть стати винайденими знаннями після створення правил за допомогою методів викрадення. Наприклад, даючи правило «яблука 
червоні», правило намагається зробити висновок, чи є об'єкт «яблуком», коли спостерігається «червоне». У цій системі викрадення спрацьовує, коли спостережувана величина (тобто червона) не дає результату класу (тобто яблуко).

Створюючи правила, система реалізує дві теореми, обговорені раніше. По-перше, вона використовує обробку природної мови для розуміння людської мови. Природна мова може знаходити синоніми, омоніми та категорії слова. У «яблука червоні» природна мова виявляє, що «червоний» - це колір, а «яблуко»іменник. Тому вона прагне знайти інші іменники, тому створює правило, таке як «(іменник) червоного кольору». Використання природної мови у цьому процесі реалізує теорему 1 .

По-друге, платформа обмінюється онтологіями з іншими датчиками Інтернету речей. Онтології побудовані таким чином, щоб правила умовиводу були зрозумілі людям. Хоча датчики Інтернету речей - машини, структура онтологій повинна передавати значення.

Запропонована інтелектуальна база масиву даних може бути застосована до різних галузей Інтернету речей (тобто розумний будинок, фермерство, розумне місто та охорона здоров'я) для автономного обміну та накопичення знань. Однак запропонована структура не стосується того, як пристрої ІоТ можуть адаптивно навчатися в обмеженому середовищі.

Платформа може використовувати онтології для інтеграції пристроїв IоT 3 інтелектуальними системами. Вибір будь-якої моделі передбачає оцінку того, наскільки критичним є додаток. Наприклад, розглядаючи правильну модель для віддаленого, критично важливого додатка, можна прийняти наявність ресурсів у хмарі за умови, що вимоги до затримки мережі та доступності мережі оптимізовані для віддаленої програми. Перевагою цієї моделі $\epsilon$ те, що датчики Інтернету речей у хмарі можуть навчатися у віддалених датчиків у фоновому режимі, незалежно від затримки мережі, що підключається до віддаленої програми. Недоліком $\epsilon$ те, що затримка мережі може стати вузьким місцем, коли потреба у прийнятті рішень у режимі реального часу зростає.

Структура усуває поточний розрив у повторному використанні онтологій у різних сферах, вимагаючи використання людської мови для іменування сутностей та відносин.

Незважаючи на те, що система вирішує поточну проблему повторного використання онтологій, вона приймає недосконале визначення інтелектуальних систем. Розумні об'єкти, наведені в тематичному дослідженні, знають і реагують на зміни у своєму середовищі, активно приймають рішення та демонструють комунікабельність 3 іншими розумними об'єктами, а також допомагають іншим. На додаток до цього сильний штучний інтелект включає прояв емоцій та бажання, формування особистого характеру, коли потрапляє в різні ситуації. Проте мало дискусій щодо того, чи повинні системи ІоТ демонструвати сильний характер штучного інтелекту, чи це може призвести до контрпродуктивності. Отже, цілісні рамки пропонують нові уявлення про інтелектуальні системи IoT.

Зближення ІоТ та масштабної аналітики даних створило величезні можливості. Машинний інтелект, заснований на даних IоT, об’єднав кібер- і фізичний світ разом і значно покращився для дослідження реальних проблем з кіберфізичної точки зору. Ефективність та надійність процесів та систем значно покращились. Тепер системні оператори мають кращий моніторинг та контроль над своїми системами та процесами, а люди з бізнес-аналітики краще розуміють свої виклики та приймають обгрунтовані рішення. Хоча зближення машинного інтелекту 
та Інтернету речей відкрило багато можливостей, $є$ кілька проблем, які стримують їх зростання.

Для вдосконалення процесу прийняття рішень алгоритми машинного навчання значною мірою покладаються на дані ІоТ, що генеруються та передаються з пристроїв IоT. У рамках ІоТ різні рівні ІоТ, наприклад, рівень сприйняття, транспортний рівень та рівень додатків, є вразливими до кібератак. Наприклад, введення зловмисного коду, фальсифікація вузлів, видавання себе за іншу особу, атаки відмови в обслуговуванні, атаки маршрутизації та атаки транзиту даних - ось деякі 3 прикладів кібератак у моделі системи ІоТ. Щоб захистити систему ІоТ від цих кіберзагроз, важливо забезпечити належну систему управління довірою. Самі пристрої ІоТ вимагають належної уваги, оскільки більшість пристроїв не мають належних механізмів захисту.

По-перше, користувачі можуть будь-коли додати рішення безпеки у традиційному IT-сценарії; однак більшість пристроїв IоT не мають рішень безпеки, а інші мають вбудовані рішення безпеки, і більшість пристроїв не підтримують додаткові виправлення безпеки, рішення чи оновлення пізніше, після виробництва пристроїв.

По-друге, через низьку пам'ять та обмеження обробки використовуються лише полегшені алгоритми.

По-третє, у середовищі ІоТ використовується широкий спектр пристроїв. Через цю неоднорідну природу ризик безпеки збільшується за рахунок інтеграції пристроїв різних типів, технологій та постачальників.

По-четверте, рівень додатків ІоТ страждає від питань конфіденційності. Витік даних та прослуховування даних можуть мати потенційні наслідки. По-п'яте, протоколи зв'язку ІоТ також вразливі до кібератак та загроз, включаючи атаки транзиту даних, маршрутизацію та DoS-атаки, проблеми в управлінні ключами, високу обчислювальну вартість та відсутність контролю користувача щодо конфіденційності.

Програми ІоТ вимагатимуть більш швидкої обробки та прийняття рішень, що призведе до наближення обробки даних до споживача. Надсилання даних у хмару вимагає часу та великої пропускної здатності. Тому аналітика на крайньому вузлі ІоТ відкрила можливість для майбутніх впливів.

Однією з причин цієї тенденції є те, що використання датчиків широко розповсюджується у багатьох сферах життя та бізнесу, таких як транспортні засоби, виробництво та охорона здоров'я, створюючи безперервні потоки даних. Така велика кількість даних стає сировиною для підприємств та урядів для отримання уявлень та нових знань, використовуючи техніки машинного навчання. Мотивація включає конкуренцію або створення кращих політик, викладених у разі, коли даних досить, що породжує актуальність отримання знань із даних.

Іншим рушієм є зближення між ІоТ та критичною інфраструктурою через їхній попит на критично важливі програми. Дані обробляються ближче до споживача, коли критична низька затримка. Сучасна тенденція полягає в тому, що тривіальні програми, як правило, стають критичними або можуть бути перероблені для підтримки критичних програм.

Проблема проти цієї тенденції полягає в тому, що крайні пристрої (наприклад, мобільні пристрої), як правило, мають нижчі обчислювальні можливості, ніж хмарний центр обробки даних. 3 іншого боку, аналіз даних машинного навчання вимагає високої обчислювальної потужності та зберігання. У цьому контексті запропонована система машинного навчання в середовищі IоT може вирішити 
цю проблему. Її майбутня робота може включати вивчення федерації крайових пристроїв, що обмінюються своїми знаннями. Крайовий пристрій, обладнаний найвищою обчислювальною продуктивністю, може виконувати завдання обробки даних. Крайовий пристрій, який має найбільшу пропускну здатність, може спілкуватися з хмарою, щоб розвантажити свої обчислювальні завдання.

Технології ІоТ дозволили платформі спілкуватися між великою кількістю пов'язаних датчиків та сенсорів. Коли критично важливі програми та кінцеві користувачі потребують великої кількості взаємозв'язків, масштабованість стає проблемою, яку необхідно вирішити. Наприклад, великі обсяги даних потрібно розподілити на декілька кінцевих пристроїв, де пристрої одночасно вирішують обчислювальні проблеми. Отже, розподілені алгоритми машинного навчання 3 крайовими обчисленнями - потенційне рішення. Це дозволяє приймати обчислювальні рішення на краю, який знаходиться ближче до пристроїв IоT.

Прогрес у дослідженні людської мови сприятиме покращенню виконання завдань машинного навчання у розподіленій системі. Людська мова ставить контекст за значеннями даних, дозволяючи підключеним пристроям ІоТ спільно призначати мітки своїм даним, вивчати знання з інших пристроїв, представляючи тим самим розподілене машинне навчання для вирішення обчислювальних задач.

В умовах гіперконвергенції сховища спільно використовуються між великою кількістю розподілених вузлів, і їхня сукупна продуктивність допомагає вирішити проблему спільного використання ресурсів.

Висновки і перспективи подальших досліджень. У роботі досліджено принципи формування масиву даних на базі нейронної мережі у сфері Інтернету речей. Пристрої ІоТ обмежені в обчислювальних та комунікаційних ресурсах, що є вузьким місцем у розробці адаптивних інтелектуальних рішень, що використовують техніки машинного навчання. Формування масиву даних на базі нейронної мережі грунтується на врахуванні семантики завдань, які вирішуються, що дозволяє зробити рішення цих задач більш структурованими та прозорими для користувача, а також дозволить вносити додаткові коректування в процес навчання нейронної мережі та рішення задач. Реалізація описаного алгоритму формування масиву даних, а також відповідної інтелектуальної середи дозволить зменшити поріг входження розробників у сферу рішення задач за допомогою нейронної мережі.

\section{СПИСОК ВИКОРИСТАНОЇ ЛІТЕРАТУРИ:}

1. Семеног А.Ю. Цифрові технології в умовах формування цифрової економіки. Наукові записки Національного університету «Острозька академія». Серія «Економіка». Острог : Вид-во НаУОА, 2020. № 19(47). С. 20-28.

2. Сотник І.М., Завражний К.Ю. Підходи до забезпечення інформаційної безпеки промислового Інтернету речей на підприємстві. Маркетинг $і$ менеджмент інновацій. 2017. № 3. С. 177-186. DOI: 10.21272/mmi.2017.3-17.

3. Аксак Н.Г. Методи та моделі розподіленої інтелектуальної обробки великих даних у спеціалізованих комп'ютерних системах : автореф. дис. ... д-ра техн. наук : 05.13.05 «Комп'ютерні системи та компоненти». М-во освіти і науки України, Харків. нац. ун-т радіоелектроніки. Харків, 2019. 44 с.

4. Проривні технології в економіці і бізнесі (досвід СС та практика України у світлі III, IV i V промислових революцій) : навчальний посібник / за ред. Л.Г. Мельника та Б.Л. Ковальова. Суми : Сумський державний університет, 2020. 180 с.

5. Balakleiets K., Kvitka A. Свропейські тренди в інноваційному підприємництві. URL: 2019. https://www.researchgate.net/publication/333609483_Evropejski_ trendi_v_innovacijnomu_pidpriemnictvi (дата звернення: 10.01.2021). 
6. Zhang W., Kumar M., Liu J. Multi-parameter online measurement IoT system based on BP neural network algorithm. Neural Computing and Applications. 2019. Vol. 31. No. 12. P. 8147-8155. DOI: 10.1007/s00521-018-3856-8.

7. Cui Dan, Liu Fei. The Application of BP Neural Network in Internet of Things. Advanced Engineering Forum. 2012. Vol. 6-7. P. 1098-1102. DOI: 10.4028/www. scientific.net/AEF.6-7.1098.

8. Xiao Han, Li, Yuanjiang. A New Thought based on the Service Composition of Automatic Transmission Semantic Grid in Internet of Things. International Journal of Advancements in Computing Technology. 2011. Vol. 3. P. 10-16. DOI: 10.4156/ijact. vol3.issue7.2.

9. Changsheng X., ZiYing Z. A New Music Classification Method based on BP Neural Network. JDCTA. 2011. Vol. 5. No. 6. P. 85-94.

10. Han Xiao, Yuanjiang Li. A New Thought based on the Service Composition of Automatic Transmission Semantic Grid in Internet of Things. IJACT. 2011. Vol. 3, No. 7. P. 10-16.

11. Ren Fang, Ma Jian-Feng. Attribute-Based Access Control Mechanism for Perceptive Layer of the Internet of Things. JDCTA. 2011. Vol. 5. No. 10. P. 396-403.

12. Naveen Dr, Raina Rohini. Machine learning in Internet of Thing. 2018. URL: https://www.researchgate.net/publication/322209934_MACHINE_LEARNING_IN_

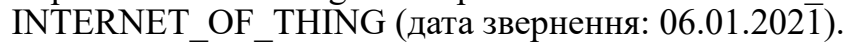

13. Li Xinwu. A New Color Correction Model for based on BP Neural Network. AISS. 2011.Vol. 3. No. 5. P. 72-78.

14. Штучний інтелект зможе попереджати хвороби корів. 2018. URL: http:// milkua.info/uk/post/stucnij-intelekt-zmoze-poperedzati-hvorobi-koriv (дата звернення : 06.08.2021).

15. Олійник П.Б. Розробка бездротового датчика вібрації на основі MEMS акселерометра. URL: https://media.neliti.com/media/publications/306711-developmentof-wireless-vibration-transd-e11dbf9c.pdf (дата звернення: 06.08.2021).

16. Мокін В.Б., Собко Б.Ю., Дратований М.В., Крижановський С.М., \& Горячев Г.В. Створення інформаційної системи моніторингу забруднення атмосферного повітря міста на основі технології «Інтернет речей». Вісник Віннищького політехнічного інституту, 2017. № 3, с. 49-58.

17. Методологія та організація наукових досліджень : навчальний посібник / І.С. Добронравова, О.В. Руденко, Л.І. Сидоренко та ін. ; за ред. І.С. Добронравової (ч. 1), О.В. Руденко (ч. 2). Київ. : ВПЦ «Київський університет», 2018. 607 с.

\section{REFERENCES:}

1. Semenoh, A.Yu. (2020). Tsyfrovi tekhnolohii v umovakh formuvannia tsyfrovoi ekonomikyi [Digital technologies in the conditions of formation of digital economy]. Naukovi zapysky Natsionalnoho universytetu "Ostrozka akademiia". Seriia "Ekonomika", 19(47), 20-28 [in Ukrainian].

2. Sotnyk, I.M., Zavrazhnyi, K.Iu. (2017). Pidkhody do zabezpechennia informatsiinoi bezpeky promyslovoho Internetu rechei na pidpryiemstvi [Approaches to information security of the industrial Internet of Things at the enterprise]. Marketynh i menedzhment innovatsii, 3, 177-186. DOI: 10.21272/mmi.2017.3-17 [in Ukrainian].

3. Aksak, N.H. (2019). Metody ta modeli rozpodilenoi intelektualnoi obrobky velykykh danykh u spetsializovanykh kompiuternykh systemakh [Methods and models of distributed intelligent processing of large data in specialized computer systems] abstract of the dissertation of the doctor of technical sciences: 05.13.05 "Computer systems and components". Ministry of Education and Science of Ukraine, Kharkiv. Nat. University of Radio Electronics. Kharkiv, 44 p. [in Ukrainian].

4. Melnik, L.G., Kovalev, B.L. ed. (2020). Proryvni tekhnolohii v ekonomitsi i biznesi (dosvid YeS ta praktyka Ukrainy u svitli III, IV i V promyslovykh revoliutsii) [Breakthrough technologies in economics and business (EU experience and practice 
of Ukraine in the light of III, IV and V industrial revolutions)]: textbook. Sumy: Sumy State University, 180 p. [in Ukrainian].

5. Balakleiets, K., Kvitka, A. (2019). Yevropeiski trendy v innovatsiinomu pidpryiemnytstvi [European trends in innovative entrepreneurship]. Retrieved from: https://www.researchgate.net/publication/333609483 Evropejski trendi_v innovacijnomu pidpriemnictvi (Last accessed: 10 January 2021) [in Ukrainian].

6. Zhang, W., Kumar, M., \& Liu, J. (2019). Multi-parameter online measurement IoT system based on BP neural network algorithm. Neural Computing and Applications, 31(12), 8147-8155.

7. Cui, D.D., \& Liu, F. (2012). The application of BP neural network in Internet of Things. In Advanced Engineering Forum. Vol. 6, pp. 1098-1102. Trans Tech Publications Ltd.

8. Xiao, H., \& Li, Y. (2011). A New Thought based on the Service Composition of Automatic Transmission Semantic Grid in Internet of Things. IJACT: International Journal of Advancements in Computing Technology, 3(7), 10-16. DOI: 10.4156/ijact. vol3.issue7.2.

9. Xiang, C., \& Zhou, Z. (2011). A new music classification method based on BP neural network. International Journal of Digital Content Technology and its Applications, 5(6), 85-94.

10. Xiao, H., \& Li, Y. (2011). A New Thought based on the Service Composition of Automatic Transmission Semantic Grid in Internet of Things. IJACT: International Journal of Advancements in Computing Technology, 3(7), 10-16.

11. Fang, R., Jian-feng, M., \& Xuan-wcn, H. (2012). Attribute-based access control scheme for the perceptive layer of the Internet of Things. Journal of Xidian University, 39(2), 66-72.

12. Naveen Dr, Raina Rohini. Machine learning in Internet of Thing. (2018). Retrieved from: https://www.researchgate.net/publication/322209934 MACHINE LEARNING_IN_INTERNET_OF_THING (Last accessed: 10 January $2 \overline{0} 21$ ).

13. Xinwü, L. (2011). A new color correction model for based on BP neural network. Advances in Information Sciences and Service Sciences, 3(5), 72-78.

14. Shtuchnyi intelekt zmozhe poperedzhaty khvoroby koriv [Artificial intelligence will be able to prevent diseases of cows]. 2018. Retrieved from: http://milkua.info/en/ post/stucnij-intelekt-zmoze-poperedzati-hvorobi-koriv (Last accessed: 06 August 2021) [in Ukrainian].

15. Oliinyk, P.B. (2021). Rozrobka bezdrotovoho datchyka vibratsii na osnovi MEMS akselerometra [Development of a wireless vibration sensor based on the MEMS accelerometer]. Retrieved from: https://media.neliti.com/media/publications/306711development-of-wireless-vibration-transd-e11dbf9c.pdf (Last accessed: 06 August 2021) [in Ukrainian].

16. Mokin, V.B., Sobko, B.Yu., Dratovanyi, M.V., Kryzhanovskyi, Ye.M., \& Horiachev, H.V. (2017). Stvorennia informatsiinoi systemy monitorynhu zabrudnennia atmosfernoho povitria mista na osnovi tekhnolohii "Internet rechei" [Creation of an information system for monitoring the city's air pollution based on the Internet of Things technology]. Visnyk Vinnytskoho politekhnichnoho instytutu, 3, 49-58 [in Ukrainian].

17. Dobronravova, I.S. (ed.), et. al. (2018). Metodolohiia ta orhanizatsiia naukovykh doslidzhen [Methodology and organization of scientific research]. Kyiv : VPTs "Kyivskyi universytet" [in Ukrainian]. 